\title{
Effects of Drying and Blanching on the Retention of Bioactive Compounds in Ginger and Turmeric
}

\author{
Haozhe Gan ${ }^{\dagger}$, Erin Charters ${ }^{\dagger}$, Robert Driscoll ${ }^{\dagger}$ and George Srzednicki * \\ School of Chemical Engineering, University of New South Wales, Sydney 2052, Australia; \\ z3365252@student.unsw.edu.au (H.G.); z3374995@student.unsw.edu.au (E.C.); r.driscoll@unsw.edu.au (R.D.) \\ * Correspondence: g.srzednicki@unsw.edu.au; Tel.: +61-2-9385-4355; Fax: +61-2-9385-5966 \\ † These co-authors graduated from the university and approved their participation in this research. \\ Academic Editors: Varit Srilaong, Mantana Buanong, Chalermchai Wongs-Aree, Sirichai Kanlayanarat \\ and Douglas D. Archbold \\ Received: 3 December 2015; Accepted: 7 April 2016; Published: 30 December 2016
}

\begin{abstract}
Ginger and turmeric, members of the Zingiberaceae family, are widely used for their pungent and aromatic flavour in foods and also for their medicinal properties. Both crops are often grown by smallholders in mountain areas on rich former forest soils with no need for fertilizers and pesticides, fulfilling de facto the conditions of organic agriculture. They are consumed fresh or dried. Drying is often performed without taking into account the content of bioactive compounds in the dried product. Various bioactive compounds have been identified in their rhizomes, and their content affects the price of the dried product. Hence, this study focused on the effects of drying treatments and blanching on the retention of bioactive compounds in the dried products. The bioactive compounds in ginger rhizome (Zingiber officinale Roscoe) are gingerols (particularly 6-gingerol). The drying treatments that were applied to fresh ginger included constant and also changing temperature conditions. Due to the short drying time, $60{ }^{\circ} \mathrm{C}$ was the optimal drying temperature to retain 6-gingerol. However, the changing temperature conditions significantly improved the retention of 6-gingerol. As for blanching, it had a significant negative effect on 6-gingerol retention. Turmeric (Curcuma longa) is known for its bright yellow colour and pharmacological properties due to curcumin, a phenolic compound. Drying was performed under constant conditions at $38^{\circ} \mathrm{C}, 48{ }^{\circ} \mathrm{C}, 57^{\circ} \mathrm{C}$ and $64{ }^{\circ} \mathrm{C}$ and a relative humidity of $20 \%$ and $40 \%$. Drying at $57{ }^{\circ} \mathrm{C}$ with a lower relative humidity was the best drying treatment, yielding the highest amount of curcumin among non-blanched samples. Blanching for $15 \mathrm{~min}$ exhibited the highest curcumin yield while blanching for $5 \mathrm{~min}$ and $30 \mathrm{~min}$ did not have much effect. The findings of this study will benefit the industry in terms of improved quality control and cost reduction.
\end{abstract}

Keywords: ginger rhizome (Zingiber officinale Roscoe); air drying; changing conditions; 6-gingerol; turmeric rhizome (Curcuma longa); blanching; curcumin

\section{Introduction}

Ginger (Zingiber officinale Roscoe) and turmeric (Curcuma longa) belong to the Zingiberaceae family. Both species are spices that are cultivated and consumed in subtropical and tropical regions all around the world. They are erect perennial herbs that are grown for their rhizomes. A rhizome is an underground plant stem that is capable of producing shoots and roots of a new plant. Rhizomes of both plants are consumed in many subtropical and tropical countries such as China, India, Jamaica and Australia. They are consumed fresh or dried. Ginger is often consumed as a condiment and served with food or in beverages as flavoured tea or soft drink, whereas turmeric is often used in dried form in curries. Both are highly regarded in culinary preparations due to their characteristic smell and 
flavour produced by volatile components and pungent components. Other important applications are in pharmacology, and their medicinal properties have been known for centuries. The moisture content (MC) of fresh ginger is between $83 \%-94 \%$ on a wet basis [1,2]. Polyphenol compounds including 10-gingerol, 8-gingerol, 6-gingerol, and their derivatives, are detected in the roots of ginger, and extracts have been proven to have high antioxidant activity [3,4] and anti-inflammatory effect [5].

The MC of fresh turmeric is about $83 \%-87 \%$ [6]. According to Parthasarathy et al. [7] turmeric contains $6.3 \%$ protein, $5.1 \%$ fat, $3.5 \%$ minerals, and $69.4 \%$ carbohydrates. The essential oil has $1 \% \alpha$-phellandrene, $0.6 \%$ sabinene, $1 \%$ cineol, $0.5 \%$ borneol, $25 \%$ zingiberene and $53 \%$ sesquiterpenes. The components of turmeric can vary amongst cultivars. In addition, the content of curcumin depends on location of growth. Curcumin is the component of turmeric responsible for its colour and all its medicinal properties. It has a molecular formula of $\mathrm{C} 21 \mathrm{H} 20 \mathrm{O} 6$ and its structure has been identified as diferuloylmethane. It is insoluble in water and soluble in ethanol and acetone. It makes up $2.5 \%-6 \%$ of the rhizome. Curcumin and its two related demethoxy compounds, demethoxycurcumin and bisdemethoxycurcumin, are known as curcuminoids. These components have been identified as antioxidants. Cyclocurcumin is a newly identified curcuminoid isolated from the fraction of turmeric found to be active as a nematicide. New phenolics have been identified as well, which are antioxidants and anti-inflammatory.

Among the bioactive compounds of interest in the rhizomes of these two plants are gingerols in ginger and curcumin in turmeric. The content of these compounds in the dried product generally determines the price of the commodity. Drying is an important processing step in the postharvest handling of ginger and turmeric as it reduces their MC and water activity, hence reducing microbial activity and chemical reactions which decrease deterioration and increase shelf life. It also reduces the size of products, which decreases storage and transportation costs. Yet, some adverse effects on product quality caused by drying cannot be ignored which include the loss of volatile aromatic compounds, decrease of antioxidant activity, and degradation of valuable nutrient content [8]. Also, the formation of some new components can take place as a result of thermal reactions [9].

Blanching in hot water after harvesting is a traditional process that removes the raw odour and improves drying time. There are conflicting views on the effect of blanching on bioactive compounds in ginger and turmeric. Thuwapanichayanan et al. [10] found that blanched ginger powder had lower total phenolic content and antioxidant activity compared to the untreated sample due to the loss of phenolics into the hot water during blanching. Some studies reported that high temperatures, such as experienced in blanching, cause thermal degradation of curcumin [11], while other studies have shown that blanching protects the bioactive ingredients from the effects of drying [12]. Therefore, this study investigated the effects of blanching time and drying conditions on the concentration of the key bioactive compounds, 6-gingerol in dried ginger, and curcumin in dried turmeric.

\section{Materials and Methods}

\subsection{Ginger and Turmeric Samples}

Mature, fresh ginger samples of Australian origin were obtained from the Buderim Ginger Pty Ltd in Yandina, Queensland, Australia. Fresh turmeric was procured as rhizomes from Earthcare Enterprises, Maleny, Queensland, Australia.

\subsection{Sample Preparation}

Ginger and turmeric samples were stored at $-18{ }^{\circ} \mathrm{C}$ in a refrigerator after procurement. Frozen samples were defrosted at $4{ }^{\circ} \mathrm{C}$ for $24 \mathrm{~h}$, and placed at ambient temperature for $12 \mathrm{~h}$ before use. Defrosted rhizomes were peeled and sliced to $4 \mathrm{~mm}$ thickness. In all drying treatments, in addition to untreated sliced samples, three batches of samples were blanched in a $70{ }^{\circ} \mathrm{C}$ water bath for 5,15 , or $30 \mathrm{~min}$, respectively. 


\subsection{Drying Treatments}

\subsubsection{Dryer}

Air drying of rhizome slices was conducted in a cabinet dryer (developed by the University of New South Wales Food Engineering Research Group) (Figure 1). The dryer consisted of a temperature and relative humidity $(\mathrm{RH})$ controller, a steam injection unit, a fan, and a drying chamber. The weight of samples was about $200 \mathrm{~g}$ for each batch. The samples were spread in a single layer on a stainless steel tray placed in the drying chamber. A load cell connected to a computer was placed below the tray for automatic recording of weight. The drying air flow was parallel to the tray surface with a constant air velocity of $0.75 \pm 0.03 \mathrm{~m} \cdot \mathrm{s}^{-1}$. The temperature and $\mathrm{RH}$ were monitored online using a data logger (Datataker DT50).

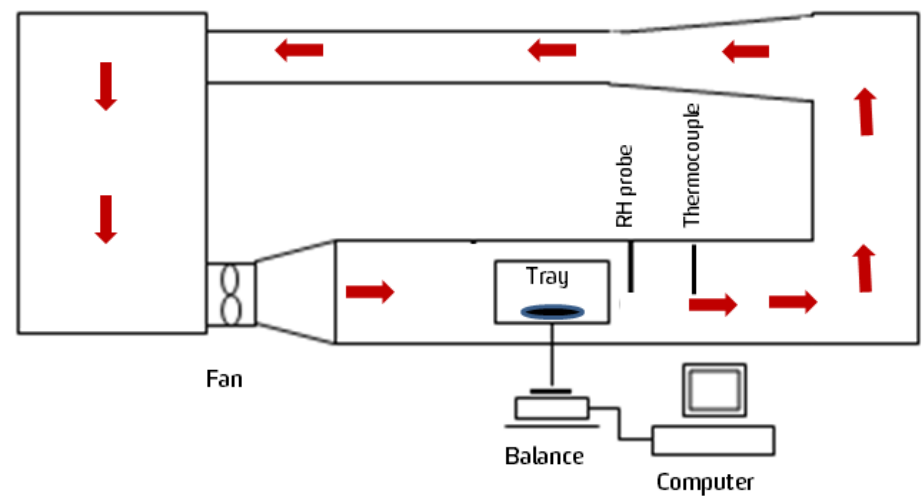

Figure 1. Schematic of the laboratory-scale cabinet dryer used in the experiments.

\subsubsection{Drying Conditions}

\section{Ginger}

Under constant conditions the drying run was stopped after a constant sample weight was reached. Under changing conditions, the change to the next condition took place when the sample weight fell to $60 \mathrm{~g}$. Then, the samples were dried until they reached a constant weight. The weights of samples were recorded online at 15 min intervals. Initial and final MCs of the ginger slices were determined in a vacuum oven according to AOAC standards [13], i.e., at $70 \pm 1{ }^{\circ} \mathrm{C}$ under $13.3 \mathrm{kPa}$ pressure for $24 \mathrm{~h}$. MC determination was the average of triplicate samples. The results were expressed as means with standard deviation. Comparison of means was done with ANOVA using EXCEL ${ }^{\mathrm{TM}}$ (Microsoft Corp., Redmond, WA, USA). The ginger samples drying treatments are in Table 1.

Table 1. Drying conditions of ginger [2].

\begin{tabular}{ccccc}
\hline S/N & Strategy & Temperature $\left({ }^{\circ} \mathbf{C}\right)$ & Relative Humidity (\%) & Blanching (min) \\
\hline 1 & Temperature control only & 40 & $9-12$ & 0 \\
2 & 40 & 40 & $9-12$ & 5 \\
3 & 40 & $9-12$ & 15 \\
4 & 50 & $9-12$ & 30 \\
5 & $6-8$ & 0 \\
\hline
\end{tabular}


Table 1. Cont.

\begin{tabular}{|c|c|c|c|c|}
\hline $\mathbf{S} / \mathbf{N}$ & Strategy & Temperature $\left({ }^{\circ} \mathrm{C}\right)$ & Relative Humidity (\%) & Blanching (min) \\
\hline \multicolumn{5}{|c|}{ Temperature \& RH Control } \\
\hline 6 & Constant conditions & 30 & 30 & 0 \\
\hline 7 & & 40 & 10 & 0 \\
\hline 8 & & 40 & 30 & 0 \\
\hline 9 & & 50 & 25 & 0 \\
\hline 10 & & 60 & 15 & 0 \\
\hline 11 & Changing conditions & 40 then 60 & 30 then 15 & 0 \\
\hline 12 & & 60 then 40 & 15 then 30 & 0 \\
\hline 13 & & 40 then 30 & 10 then 30 & 0 \\
\hline 14 & & 30 then 40 & 30 then 10 & 0 \\
\hline 15 & & 50 then 60 & 25 then 15 & 0 \\
\hline 16 & & 60 then 50 & 15 then 25 & 0 \\
\hline
\end{tabular}

Turmeric

The turmeric samples were subjected to drying treatments as shown in Table 2. Turmeric samples were dried under constant conditions only. MC was determined in the same way as in ginger [13].

Table 2. Drying conditions turmeric.

\begin{tabular}{cccc}
\hline S/N & Temperature $\left({ }^{\circ} \mathbf{C}\right)$ & Relative Humidity $(\%)$ & Blanching (min) \\
\hline 1 & 40 & 20 & 0 \\
2 & 40 & 40 & 0 \\
3 & 50 & 20 & 0 \\
4 & 50 & 20 & 5 \\
5 & 50 & 20 & 15 \\
6 & 50 & 20 & 30 \\
7 & 60 & 20 & 0 \\
8 & 60 & 40 & 0 \\
9 & 70 & 20 & 0 \\
\hline
\end{tabular}

\subsection{Determination of Bioactive Compounds}

\subsubsection{Gingerol}

\section{Extraction}

The 6-gingerol ( $\gg 98 \%$ purity) standard was obtained from Sigma-Aldrich (St. Louis, MO, USA). Methanol was of HPLC grade. Water for HPLC analysis was purified with a Milli-Q system (Merck, KGaA, Darmstadt, Germany). A stock solution of 6-gingerol in methanol $(5.0 \mathrm{mg} / \mathrm{mL})$ was prepared to produce a series of dilutions. The dilutions were prepared from the stock solution by dilution with $10 \%$ methanol and $90 \%$ water. For establishing standard curves, the solutions were prepared containing 5 , $10,20,40,60,80$ and $100 \mu \mathrm{g} / \mathrm{mL}$, respectively. All solutions were stored in amber glass bottles at $4{ }^{\circ} \mathrm{C}$ before use.

Dried and fresh ginger ware pulverized and passed through a 40 mesh $(0.42 \mathrm{~mm})$ sieve before extraction. A powder sample ( $1 \mathrm{~g})$ from each treatment was dissolved in $25 \mathrm{~mL}$ methanol and sonicated for $30 \mathrm{~min}$. The mixtures were centrifuged at 10,000 rpm for $10 \mathrm{~min}$ and supernatant was filtered through Whatman filter paper (No. 1). Then, it was diluted with water until the final solvent ratio was $10 \%$ methanol and $90 \%$ water. All the extracts were kept at $4{ }^{\circ} \mathrm{C}$. Extracts of ginger were filtered through a $0.45 \mu \mathrm{m}$ nylon filter into an Agilent amber vial with cap and a wide opening for HPLC analysis. 
Instrumentation and Chromatographic Conditions

A Prominence LC-20AD HPLC system (Shimadzu, Kyoto, Japan) was used in this study. The separation of the extract was conducted using a C18 column, $3.5 \mu \mathrm{m}, 2.1 \times 150 \mathrm{~mm}$. Water (A) and methanol (B) constituted the mobile phase which was used for separation. The gradient elution had the following profile: $0-5 \mathrm{~min}, 50 \%-60 \% \mathrm{~B}$; 5-9 $\mathrm{min}, 60 \% \mathrm{~B}$; 9-14 $\mathrm{min}, 60 \%-95 \% \mathrm{~B} ; 14-15 \mathrm{~min}$, $95 \% \mathrm{~B} ; 15-16 \mathrm{~min}, 95 \%-50 \% \mathrm{~B} ; 16-25 \mathrm{~min}, 50 \% \mathrm{~B}$. The injection volume was $40 \mu \mathrm{L}$ and the flow rate was $0.18 \mathrm{~mL} / \mathrm{min}$. The UV detector $(0 \sim 1000 \mathrm{~nm})$ wavelength was set at $281 \mathrm{~nm}$ and the column temperature was maintained at $30^{\circ} \mathrm{C}$.

\subsubsection{Curcumin}

\section{Extraction}

Dried samples were ground in a Pulverisette, type 14,202 laboratory mill (Fritsch, Idar-Oberstein, Germany) at 15,000 rpm with a $1 \mathrm{~mm}$ mesh screen and stored in glass flasks. The powdered samples $(10 \mathrm{~g})$ were extracted with dichloromethane using a Soxhlet extractor in a water bath at $70{ }^{\circ} \mathrm{C}$ for $1.5 \mathrm{~h}$. The extract was concentrated in a rotary evaporator, then diluted in ethanol. The curcumin standard (Sigma-Aldrich) was used for identification and quantitation. A calibration curve was produced using the following concentrations of the standard: 30, 100, 300, 700 and $1000 \mathrm{ng} / \mathrm{mL}$.

Instrumentation and Chromatographic Conditions

The same HPLC as for 6-gingerol was used for curcumin detection. The separation of the extract was performed using a C18 column, $2 \mu \mathrm{m}, 2.1 \times 150 \mathrm{~mm}$. Formic acid (0.1\%) (A) and acetonitrile (B) constituted the mobile phase which was used for separation. The gradient elution profile is shown in Table 3. The injection volume was $5 \mu \mathrm{L}$. The detector wavelength was set at $360 \mathrm{~nm}$.

Table 3. The gradient elution profile.

\begin{tabular}{ccccc}
\hline Step & Time (min) & A $\%$ & $\mathbf{B} \%$ & Flow Rate $(\mathbf{m L} / \mathbf{m i n})$ \\
\hline 0 & 0.00 & 99.5 & 0.5 & 6.0 \\
1 & 0.34 & 99.5 & 0.5 & 6.0 \\
2 & 1.40 & 45.0 & 55.0 & 6.0 \\
3 & 4.50 & 40.0 & 60.0 & 6.0 \\
4 & 4.80 & 0.5 & 99.5 & 7.5 \\
5 & 6.60 & 0.5 & 99.5 & 7.5 \\
6 & 7.00 & 99.5 & 0.5 & 7.5 \\
7 & 10.00 & 99.5 & 0.5 & 7.5 \\
\hline
\end{tabular}

\section{Results}

\subsection{Drying}

\subsubsection{Ginger}

The MC of fresh rhizomes was between $536 \%-904 \%$ on a dry basis $(\mathrm{db})$ (Table 4$)$. A higher temperature and lower $\mathrm{RH}$ of the drying air led to lower a MC (i.e., higher moisture loss) of the final product. Treatments with higher RH in the dryer produced a higher MC in the final product. The results of changing conditions indicated that treatments with mild temperature and humidity conditions at the initial stage led to a higher MC of the dried sample, while initial harsh conditions caused a lower MC. Thus, the initial conditions of air drying are a primary factor determining final MC of the product. The results of blanching as a pre-treatment of ginger slices (Table 4) showed that blanched slices were generally less hygroscopic than non-blanched slices. The MCs of fresh ginger after 15 and 30 min were on average $383 \%$ db lower than those of fresh ginger without blanching. This could 
be due to gelatinisation of starch molecules which may have blocked sorption sites and reduced water adsorption. A less hygroscopic polymer network may have formed around the blanched surfaces, thus disfavoring moisture adsorption.

\subsubsection{Turmeric}

The final MCs decreased with an increase in temperature, a decrease in relative humidity and a shorter blanching time (Table 5).

Table 4. Moisture content (MC) of samples subjected to different drying treatments.

\begin{tabular}{ccc}
\hline Treatment & Fresh MC (\% db) & Dried MC (\% db) \\
\hline $40^{\circ} \mathrm{C} / 9-12 \%$ RH/No blanching & $904^{\mathrm{b}} \pm 3$ & $11.9^{\mathrm{f}} \pm 0.2$ \\
$40^{\circ} \mathrm{C} / 9-12 \% \mathrm{RH} / 5$ min blanching & $922^{\mathrm{a}} \pm 5$ & $10.7^{\mathrm{g}} \pm 0.3$ \\
$40^{\circ} \mathrm{C} / 9-12 \% \mathrm{RH} / 15$ min blanching & $523^{\mathrm{i}} \pm 2$ & $9.7^{\mathrm{g}} \pm 0.2$ \\
$40^{\circ} \mathrm{C} / 9-12 \% \mathrm{RH} / 30$ min blanching & $519^{\mathrm{i}} \pm 1$ & $10.3^{\mathrm{g}} \pm 0.2$ \\
$50{ }^{\circ} \mathrm{C} / 6 \%-8 \% \mathrm{RH}$ & $935^{\mathrm{a}} \pm 1$ & $8.5^{\mathrm{h}} \pm 0.3$ \\
$60^{\circ} \mathrm{C} / 15 \% \mathrm{RH}$ & $536^{\mathrm{h}} \pm 4$ & $7.5^{\mathrm{i}} \pm 0.2$ \\
$50{ }^{\circ} \mathrm{C} / 25 \% \mathrm{RH}$ & $604^{\mathrm{f}} \pm 2$ & $11.0^{\mathrm{f}} \pm 0.2$ \\
$40^{\circ} \mathrm{C} / 30 \% \mathrm{RH}$ & $924^{\mathrm{a}} \pm 3$ & $18.4^{\mathrm{c}} \pm 0.2$ \\
$40^{\circ} \mathrm{C} / 10 \% \mathrm{RH}$ & $666^{\mathrm{e}} \pm 3$ & $10.2^{\mathrm{g}} \pm 0.3$ \\
$30{ }^{\circ} \mathrm{C} / 30 \% \mathrm{RH}$ & $587^{\mathrm{f}} \pm 5$ & $21.6^{\mathrm{a}} \pm 0.2$ \\
$60^{\circ} \mathrm{C} / 15 \% \mathrm{RH}$ to $50^{\circ} \mathrm{C} / 25 \% \mathrm{RH}$ & $761^{\mathrm{d}} \pm 1$ & $13.8^{\mathrm{e}} \pm 0.2$ \\
$50^{\circ} \mathrm{C} / 25 \% \mathrm{RH}$ to $60^{\circ} \mathrm{C} / 15 \% \mathrm{RH}$ & $865^{\mathrm{c}} \pm 1$ & $17.8^{\mathrm{d}} \pm 0.2$ \\
$60^{\circ} \mathrm{C} / 15 \% \mathrm{RH}$ to $40{ }^{\circ} \mathrm{C} / 30 \% \mathrm{RH}$ & $596^{\mathrm{f}} \pm 4$ & $20.2^{\mathrm{b}} \pm 0.2$ \\
$40^{\circ} \mathrm{C} / 30 \% \mathrm{RH}$ to $60^{\circ} \mathrm{C} / 15 \% \mathrm{RH}$ & $566^{\mathrm{g}} \pm 4$ & $20.5^{\mathrm{b}} \pm 0.2$ \\
$40^{\circ} \mathrm{C} / 10 \% \mathrm{RH}$ to $30^{\circ} \mathrm{C} / 30 \% \mathrm{RH}$ & $634^{\mathrm{e}} \pm 3$ & $11.8^{\mathrm{c}} \pm 0.2$ \\
$30^{\circ} \mathrm{C} / 30 \% \mathrm{RH}$ to $40^{\circ} \mathrm{C} / 10 \% \mathrm{RH}$ & $671^{\mathrm{b}} \pm 3$ & $19.4^{\mathrm{f}} \pm 0.2$ \\
\hline
\end{tabular}

Values are mean \pm standard deviation of triplicate analyses. In the same column, values followed by the same letter are not significantly different $(p \leq 0.05)$.

Table 5. Moisture characteristics of turmeric slices subjected to different drying treatments.

\begin{tabular}{ccc}
\hline Treatment & Fresh MC (\% db) & Dried MC (\% db) \\
\hline $40^{\circ} \mathrm{C} / 20 \% \mathrm{RH}$ & $190^{\mathrm{g}} \pm 3$ & $7.4^{\mathrm{b}} \pm 0.2$ \\
$40^{\circ} \mathrm{C} / 40 \% \mathrm{RH}$ & $335^{\mathrm{e}} \pm 3$ & $10.5^{\mathrm{a}} \pm 0.3$ \\
$50^{\circ} \mathrm{C} / 20 \% \mathrm{RH}$ & $377^{\mathrm{d}} \pm 3$ & $7.0^{\mathrm{c}} \pm 0.1$ \\
$50{ }^{\circ} \mathrm{C} / 20 \% \mathrm{RH} / 5$ min blanching & $530^{\mathrm{a}} \pm 3$ & $5.7^{\mathrm{d}} \pm 0.2$ \\
$50^{\circ} \mathrm{C} / 20 \% \mathrm{RH} / 15$ min blanching & $420^{\mathrm{c}} \pm 3$ & $7.0^{\mathrm{c}} \pm 0.3$ \\
$50^{\circ} \mathrm{C} / 20 \% \mathrm{RH} / 30$ min blanching & $490^{\mathrm{b}} \pm 2$ & $7.9^{\mathrm{b}} \pm 0.3$ \\
$60^{\circ} \mathrm{C} / 20 \% \mathrm{RH}$ & $274^{\mathrm{f}} \pm 3$ & $5.2^{\mathrm{e}} \pm 0.2$ \\
$60^{\circ} \mathrm{C} / 40 \% \mathrm{RH}$ & $256^{\mathrm{f}} \pm 2$ & $7.6^{\mathrm{b}} \pm 0.3$ \\
$70{ }^{\circ} \mathrm{C} / 20 \% \mathrm{RH}$ & $325^{\mathrm{e}} \pm 4$ & $6.1^{\mathrm{d}} \pm 0.1$ \\
\hline
\end{tabular}

Values are mean \pm standard deviation of triplicate analyses. In the same column, values followed by the same letter are not significantly different $(p \leq 0.05)$.

\subsubsection{Retention of 6-Gingerol in Ginger}

The peak of 6-gingerol is shown in Figure 2a. A linear regression between retention area and standard concentration was calculated and a coefficient of determination (R2) of 0.9788 was obtained showing a good linear relationship. Under constant drying conditions, the content of 6-gingerol decreased with increasing temperature and RH. Under changing conditions, it appeared that with specific combinations of drying conditions, the concentration of 6-gingerol significantly increased when compared with constant conditions (Table 6). 


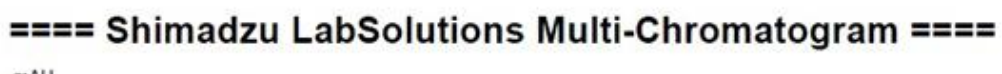

MAU

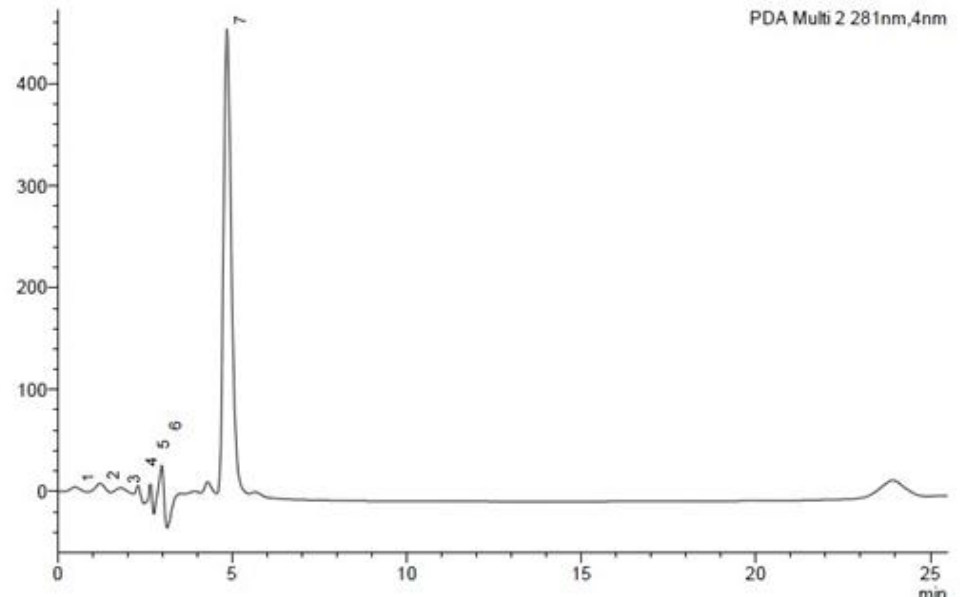

(a)

mAU

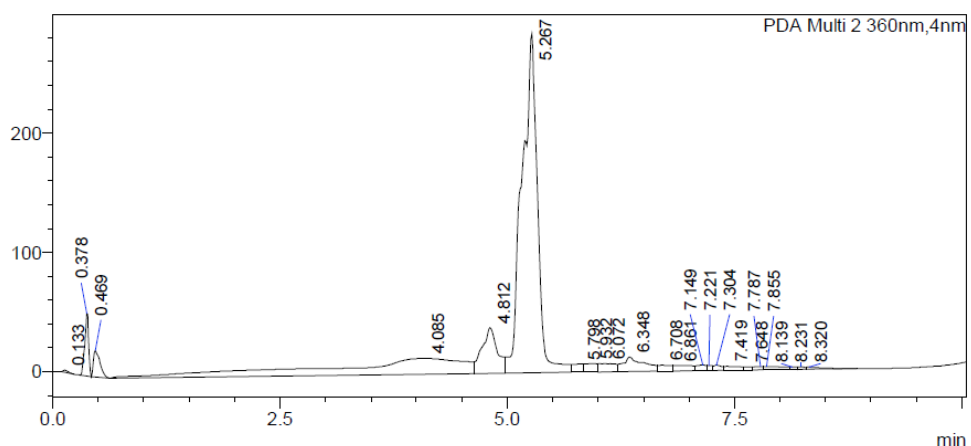

(b)

Figure 2. (a) Peak of 6-gingerol (peak \#7); (b) Peak of curcumin from a drying treatment of $60{ }^{\circ} \mathrm{C}$ $20 \% \mathrm{RH}$.

Table 6. Effects of different drying treatments on 6-gingerol concentration in dried samples.

\begin{tabular}{|c|c|c|c|}
\hline Treatment & Retention Area & $\begin{array}{c}\text { 6-Gingerol } \\
\text { Concentration }(\%)\end{array}$ & Drying Time (min) \\
\hline $40{ }^{\circ} \mathrm{C} / 9 \%-12 \% \mathrm{RH}$ & 3572383 & $1.273^{\mathrm{e}} \pm 0.063$ & $343^{d} \pm 3$ \\
\hline $40{ }^{\circ} \mathrm{C} / 9 \%-12 \% \mathrm{RH} / 5 \mathrm{~min}$ blanching & 2289876 & $0.773^{\mathrm{i}} \pm 0.005$ & $353^{d} \pm 3$ \\
\hline $40{ }^{\circ} \mathrm{C} / 9 \%-12 \% \mathrm{RH} / 15 \mathrm{~min}$ blanching & 1196832 & $0.348^{\mathrm{j}} \pm 0.012$ & $353^{d} \pm 3$ \\
\hline $40^{\circ} \mathrm{C} / 9 \%-12 \% \mathrm{RH} / 30 \mathrm{~min}$ blanching & 1059796 & $0.294^{\mathrm{j}} \pm 0.005$ & $831^{\mathrm{a}} \pm 4$ \\
\hline $50{ }^{\circ} \mathrm{C} / 6 \%-9 \% \mathrm{RH}$ & 3037359 & $1.064^{\mathrm{h}} \pm 0.010$ & $289^{\mathrm{e}} \pm 3$ \\
\hline $60^{\circ} \mathrm{C} / 15 \% \mathrm{RH}$ & 2991478 & $1.047^{\mathrm{h}} \pm 0.015$ & $177^{\mathrm{h}} \pm 3$ \\
\hline $50{ }^{\circ} \mathrm{C} / 25 \% \mathrm{RH}$ & 3306548 & $1.169 \mathrm{~g} \pm 0.011$ & $233^{g} \pm 4$ \\
\hline $40{ }^{\circ} \mathrm{C} / 30 \% \mathrm{RH}$ & 3659751 & $1.307^{\mathrm{d}} \pm 0.067$ & $297^{\mathrm{e}} \pm 3$ \\
\hline $40{ }^{\circ} \mathrm{C} / 10 \% \mathrm{RH}$ & 3702015 & $1.323^{\mathrm{d}} \pm 0.005$ & $257^{\mathrm{f}} \pm 2$ \\
\hline $30{ }^{\circ} \mathrm{C} / 30 \% \mathrm{RH}$ & 3512811 & $1.250^{\mathrm{f}} \pm 0.050$ & $489^{b} \pm 3$ \\
\hline $60{ }^{\circ} \mathrm{C} / 15 \% \mathrm{RH}$ to $50{ }^{\circ} \mathrm{C} / 25 \% \mathrm{RH}$ & 4155793 & $1.500^{b} \pm 0.036$ & $185^{\mathrm{h}} \pm 4$ \\
\hline $50{ }^{\circ} \mathrm{C} / 25 \% \mathrm{RH}$ to $60{ }^{\circ} \mathrm{C} / 15 \% \mathrm{RH}$ & 4007405 & $1.442^{\mathrm{c}} \pm 0.050$ & $203^{h} \pm 3$ \\
\hline $60{ }^{\circ} \mathrm{C} / 15 \% \mathrm{RH}$ to $40{ }^{\circ} \mathrm{C} / 30 \% \mathrm{RH}$ & 3532484 & $1.257^{\mathrm{e}} \pm 0.005$ & $193^{h} \pm 3$ \\
\hline $40{ }^{\circ} \mathrm{C} / 30 \% \mathrm{RH}$ to $60^{\circ} \mathrm{C} / 15 \% \mathrm{RH}$ & 3675330 & $1.313^{\mathrm{d}} \pm 0.054$ & $257^{\mathrm{f}} \pm 2$ \\
\hline $30{ }^{\circ} \mathrm{C} / 30 \% \mathrm{RH}$ to $40{ }^{\circ} \mathrm{C} / 10 \% \mathrm{RH}$ & 4470837 & $1.623^{\mathrm{a}} \pm 0.025$ & $425^{c} \pm 2$ \\
\hline $40{ }^{\circ} \mathrm{C} / 10 \% \mathrm{RH}$ to $30{ }^{\circ} \mathrm{C} / 30 \% \mathrm{RH}$ & 4458393 & $1.618^{\mathrm{a}} \pm 0.025$ & $305^{\mathrm{e}} \pm 3$ \\
\hline
\end{tabular}

Values are mean \pm standard deviation of triplicate analyses. In the same column, values followed by the same letter are not significantly different $(p \leq 0.05)$. 
The combined treatments of $60{ }^{\circ} \mathrm{C} 15 \% \mathrm{RH}$ and $50{ }^{\circ} \mathrm{C} 25 \% \mathrm{RH}$ resulted in $0.35 \%$ more 6 -gingerol retention vs. either of the constant conditions. Mild conditions as initial treatment led to higher 6-gingerol concentration. Blanching treatment reduced 6-gingerol retention. After 5 min of blanching, almost half of the 6-gingerol was lost vs. samples without blanching, and it decreased further with 15 and 30 min of blanching, possibly due to the high temperature of blanching.

\subsubsection{Retention of Curcumin in Turmeric}

The chromatogram indicated a curcumin peak at $5.267 \mathrm{~min}$ (Figure $2 \mathrm{~b}$ ). The greatest curcumin content (area under the curve) with samples dried at $50{ }^{\circ} \mathrm{C} 20 \% \mathrm{RH}$ and blanched for $15 \mathrm{~min}$. The greatest content for the non-blanched samples was at $60{ }^{\circ} \mathrm{C} 20 \% \mathrm{RH}$ which had $82.2 \%$ of the content of the highest samples (Table 7).

Table 7. Effects of different drying treatments on curcumin concentration in dried samples.

\begin{tabular}{ccc}
\hline Treatment & Area under the Curve & Normalised Concentration (\%) \\
\hline $40^{\circ} \mathrm{C} / 20 \% \mathrm{RH}$ & 3308511 & 73.7 \\
$40{ }^{\circ} \mathrm{C} / 40 \% \mathrm{RH}$ & 2646929 & 58.9 \\
$50{ }^{\circ} \mathrm{C} / 20 \% \mathrm{RH}$ & 3447014 & 76.8 \\
$50^{\circ} \mathrm{C} / 20 \% \mathrm{RH} / 5 \mathrm{~min}$ blanching & 3506873 & 78.1 \\
$50^{\circ} \mathrm{C} / 20 \% \mathrm{RH} / 15 \mathrm{~min}$ blanching & 4490862 & 100.0 \\
$50^{\circ} \mathrm{C} / 20 \% \mathrm{RH} / 30 \mathrm{~min}$ blanching & 3375932 & 75.2 \\
$60^{\circ} \mathrm{C} / 20 \% \mathrm{RH}$ & 3691512 & 82.2 \\
$60^{\circ} \mathrm{C} / 40 \% \mathrm{RH}$ & 2953344 & 65.8 \\
$70^{\circ} \mathrm{C} / 20 \% \mathrm{RH}$ & 3327375 & 74.1 \\
\hline
\end{tabular}

\section{Conclusions}

The following conclusions were drawn from the study:

- Increasing drying temperature decreased 6-gingerol content in the dried product.

- Changing drying conditions significantly increased the concentration of 6-gingerol.

- Blanching treatment had a significant negative effect on 6-gingerol retention.

- Increasing drying temperature at low RH tended to increase curcumin retention.

- Blanching for 15 min favoured curcumin retention in the dried product.

Author Contributions: Haozhe Gan conducted the research on drying of ginger, conceived and designed the experiments, performed the experiments and analysed the data. Erin Charters conducted the research on drying of turmeric, conceived and designed the experiments, performed the experiments and analysed the data. George Srzednicki and Robert Driscoll wrote the paper.

Conflicts of Interest: The authors declare no conflict of interest.

\section{References}

1. Phoungchandang, S.; Saentaweesuk, S. Effect of two stage, tray and heat pump assisted-dehumidified drying on drying characteristics and qualities of dried ginger. Food Bioprod. Process. 2010, 89, 429-437. [CrossRef]

2. Gan, H. Effects of Air Drying Treatments on the Concentration of the Key Bioactive Compound 6-Gingerol in Ginger. Master's Thesis, School of Chemical Engineering, The University of New South Wales, Sydney, Australia, 15 December 2013.

3. Stoilova, I.; Krastanov, A.; Stoyanova, A.; Denev, P.; Gargova, S. Antioxidant activity of a ginger extract (Zingiber officinale). Food Chem. 2007, 102, 764-770. [CrossRef]

4. Sakulnarmrat, K.; Srzednicki, G.; Konczak, I. Antioxidant, enzyme inhibitory and antiproliferative activity of polyphenolic-rich fraction of commercial dry ginger powder. Int. J. Food Sci. Tech. 2015. [CrossRef]

5. Dugasani, S.; Pichika, M.R.; Nadarajah, V.D.; Balijepalli, M.K.; Tandra, S.; Korlakunta, J.N. Comparative antioxidant and anti-inflammatory effects of 6-gingerol, 8-gingerol, 10-gingerol and 6-shogaol. J. Ethnopharmacol. 2010, 127, 515-520. [CrossRef] [PubMed] 
6. Charters, E. The Effects of Drying and Blanching on Curcumin Yields of Root Turmeric. Bachelor's Thesis, School of Chemical Engineering, The University of New South Wales, Sydney, Australia, 31 October 2014.

7. Parthasarathy, V.A.; Chempakam, B.; Zachariah, T.J. Chemistry of Spices; Centre for Agriculture and Bioscience International (CABI): Wallingford, CO, USA, 2008.

8. Chan, E.; Lim, Y.Y.; Wong, S.K.; Lim, K.K.; Tan, S.P.; Lianto, F.S.; Yong, M.Y. Effects of different drying methods on the antioxidant properties of leaves and tea of ginger species. Food Chem. 2009, 113, 166-172. [CrossRef]

9. Chen, C.C.; Ho, C.T. Volatile compounds in ginger oil generated by thermal treatment. ACS Symp. Ser. 1989, 409, 366-375.

10. Thuwapanichayanan, R.; Phowong, C.; Jaisut, D.; Štencl, J. Effects of pretreatments and drying temperatures on drying characteristics, antioxidant properties and color of ginger slice. Acta Univ. Agric. Silv. Mendel. Brun. 2014, 62, 1125-1134. [CrossRef]

11. Chen, L.; Bai, G.; Yang, S.; Yang, R.; Zhao, G.; Xu, C.; Leung, W. Encapsulation of curcumin in recombinant human H-chain ferritin increases it water-solubility and stability. Food Res. Int. 2014, 62, 1147-1153. [CrossRef]

12. Blasco, M.; Garcia-Perez, J.V.; Bon, J.; Carreres, J.E.; Mulet, A. Effect of blanching and air flow rate on turmeric drying. Food Sci. Technol. Int. 2006, 12, 315-323. [CrossRef]

13. Association of Official Analytical Chemists (AOAC). AOAC Official Methods of Analysis of AOAC International. AOAC Official Method 934.06, Moisture in Dried Fruits; Association of Official Analytical Chemists (AOAC): Rockville, MD, USA, 1997.

(C) 2016 by the authors; licensee MDPI, Basel, Switzerland. This article is an open access article distributed under the terms and conditions of the Creative Commons Attribution (CC-BY) license (http://creativecommons.org/licenses/by/4.0/). 